\title{
Duloxetine-Induced Liver Injury: A Case Report
}

\author{
Bilal Malik $^{1}$, Basel Abdelazeem ${ }^{1}$, Taylor Revere ${ }^{2}$, Nischit Baral ${ }^{1}$, Arvind Kunadi ${ }^{3}$ \\ 1. Internal Medicine, McLaren Health Care, Michigan State University, Flint, USA 2. Medical Education, Michigan State \\ University College of Human Medicine, Flint, USA 3. Internal Medicine/Nephrology, McLaren Health Care, Michigan \\ State University, Flint, USA
}

Corresponding author: Bilal Malik, bilal.malik@mclaren.org

\begin{abstract}
We present a case of a young (43-year-old), otherwise healthy, female patient who developed drug-induced liver injury (DILI) secondary to routine use of duloxetine. Our case aims to raise awareness amongst physicians about the possibility of duloxetine-induced liver injury. We recommend monitoring liver function tests (LFTs) when initiating or adjusting the dose of duloxetine, and intermittently thereafter, to facilitate early identification and management of potential DILI.
\end{abstract}

Categories: Family/General Practice, Internal Medicine, Gastroenterology

Keywords: transaminitis, duloxetine, antidepressant, hepatitis, liver injury, lfts, inflammation

\section{Introduction}

Drug-induced liver injury (DILI) is a rare entity with an incidence rate of 19 per 100,000 treated individuals [1]. DILI and acetaminophen overdose are the most common causes of acute liver failure in the United States, $13 \%$ and $39 \%$, respectively, compared to $12 \%$ for viral hepatitis A and B combined [2]. The drugs typically implicated include, but are not limited to, pain medications, various anti-microbials, and central nervous system agents $[3,4]$.

Duloxetine, a selective serotonin and norepinephrine reuptake inhibitor (SSNRI), is approved to treat depression, anxiety, and neuropathic pain, but is rarely reported to cause hepatic injury in healthy individuals. We present a rare case of duloxetine-induced hepatotoxicity in an otherwise healthy adult female. Our case aims to raise awareness amongst physicians about the possibility of duloxetine-induced liver injury. We recommend monitoring liver function tests (LFTs) when initiating or adjusting the dose of duloxetine, and intermittently thereafter.

\section{Case Presentation}

A previously healthy 43-year-old Caucasian female with a past medical history of fibromyalgia, narcolepsy, and chronic pain syndrome presented to the emergency department with gradually worsening pain in the epigastric and right hypochondriac regions over a six-day period. She described the pain as mild to moderate, exacerbated by eating but not coughing, breathing, defecation, urination, or menses. She denied any prior history of gastrointestinal (GI) complaints, family history of a hepatobiliary disease or liver transplant, and alcohol or drug use. She reported associated malaise, decreased appetite, and moderate nausea. She had several episodes of vomiting, constipation, and non-painful, dark-colored urine. The patient's home medications included duloxetine $90 \mathrm{mg}$ once daily, modafinil $200 \mathrm{mg}$ twice daily, and multiple vitamins. She had been on the same dose of duloxetine for five years prior to the onset of this episode and denied having any recent changes made to her medication regimen. She denied alcohol, nonsteroidal anti-inflammatory drugs, acetaminophen, aspirin, and recent antibiotic use. Additionally, she denied any exposure to sexually transmitted infections and contaminated food or water.

On physical examination, her vitals were stable, though she appeared to be in moderate distress. Her skin was jaundiced, and scleral icterus was evident. Lung and cardiac examinations were clear to auscultation bilaterally, with a regular rate and rhythm, without murmurs, gallops, or rubs, respectively. On abdominal examination, she was mildly tender to palpation in the epigastric and right hypochondriac regions, with no guarding, rebound tenderness and a negative Murphy's sign. On neurological examination, she was alert and oriented with no notable asterixis in outstretched arms.

Routine labs were performed, including complete blood count (CBC) and complete metabolic profile (CMP), and were all within normal limits except for her hepatic enzymes. Alanine transaminase (ALT), aspartate transaminase (AST), alkaline phosphatase, ammonia, and total bilirubin were elevated, as displayed in Table 1. Additionally, lipase, prothrombin, and international normalized ratio (PT/INR) were within normal limits, and her blood alcohol was zero. Urinalysis was abnormal, with orange-colored urine, moderate bilirubin, and trace albumin, but negative white blood cells (WBC), red blood cells (RBC), and nitrates. Urine pH was in the normal range. 


\section{Cureus}

\begin{tabular}{|c|c|c|c|}
\hline & Initial lab values (Hospital day 1) & $\begin{array}{l}\text { Discharge lab values (Hospital } \\
\text { day 11) }\end{array}$ & Normal Range \\
\hline \multicolumn{4}{|l|}{ СВС } \\
\hline WBC Count & 7.03 & 7.81 & $4.5-10 \times 10^{\star} 3 / \mathrm{uL}$ \\
\hline \multicolumn{4}{|l|}{ CMP } \\
\hline AST & 1347 & 770 & 13-35 U/L \\
\hline ALT & 3365 & 1361 & 13-35 U/L \\
\hline Alkaline Phosphatase & 237 & 240 & $41-126 \mathrm{U} / \mathrm{L}$ \\
\hline lotal Bllirubin & 7.3 & 5.4 & 0.2 to $1.2 \mathrm{mg} / \mathrm{dL}$ \\
\hline Ammonia Venous & 38 & 39 & 11032 umol/L \\
\hline Iron & 251 & - & $50-179$ ug/dL \\
\hline $\begin{array}{l}\text { Total Iron Binding Capacity } \\
\text { (TIBC) }\end{array}$ & 373 & - & $228-460 \mathrm{ug} / \mathrm{dL}$ \\
\hline Iron Saturation Percent & $6 \% .29$ & -5 & $\begin{array}{l}12.00-45.00 \% \\
\text { saturation }\end{array}$ \\
\hline Ferritin & 2542.7 & 2190.5 & $10.0-291.0 \mathrm{ng} / \mathrm{mL}$ \\
\hline Prothrombin Time & 10.4 & 10.2 & $9.5-12.0 \mathrm{sec}$ \\
\hline INR & 1.00 & 0.94 & $0.88-1.11$ \\
\hline Lipase & 194 & - & 79-393 U/L \\
\hline \multicolumn{4}{|l|}{ OIHER } \\
\hline Alpha-1 Antitrypsin & 179 & - & $99.0-242.0 \mathrm{mg} / \mathrm{dL}$ \\
\hline $\begin{array}{l}\text { Alpha-fetoprotein Tumor } \\
\text { Marker }\end{array}$ & 3.4 & - & $0.0-7.9 \mathrm{ng} / \mathrm{mL}$ \\
\hline Anti-Mitochondrial Antibody & 4.6 & - & $<=20$ Units \\
\hline Anti-nuclear Antibody & Negative & - & Negative \\
\hline Ceruloplasmin & 31.3 & - & $20.0-60.0 \mathrm{mg} / \mathrm{dL}$ \\
\hline $\begin{array}{l}\text { Hemochromatosis, Hereditary } \\
\text { DNA }\end{array}$ & $\begin{array}{l}\text { Negative for } \mathrm{C} 282 \mathrm{Y} \text { and } \mathrm{H} 63 \mathrm{D} \text { variants in } \\
\text { HFE gene }\end{array}$ & - & Negative \\
\hline $\begin{array}{l}\text { Smooth Muscle (r-actin) IgG } \\
\text { Antibody }\end{array}$ & 9 & - & $<20$ Units \\
\hline Covid-19 Antigen & Negative & - & Negative \\
\hline Hepatitis A lgM & Non-reactive & - & Non-reactive \\
\hline Hepatitis B Surface Antigen & Non-reactive & - & Non-reactive \\
\hline Hepatitis B Core Antibody lgM & Non-reactive & - & Non-reactive \\
\hline Hepatitis C Antibody & Non-reactive & - & cti \\
\hline
\end{tabular}

\section{TABLE 1: Laboratory work up results at admission and at the day of discharge}

CBC: complete blood count; WBC: white blood cells; CMP: complete metabolic profile; AST: aspartate transaminase; ALT: alanine transaminase; INR: international normalized ratio; IgG: immunoglobulin G; IgM: immunoglobulin M.

An ultrasound of the gall bladder was significant for a contracted gallbladder. No gallstones were present. CT of the abdomen and pelvis was unremarkable, with no inflammatory process identified. 


\section{Cureus}

The patient was admitted to the hospital for further evaluation and treatment of acute liver failure. She received IV fluids, lactulose for mildly elevated ammonia levels, and her home medications were held. During her admission, gastroenterology was consulted for further evaluation of her abdominal complaints. An abdominal X-ray was performed and negative for obstruction. She received a suppository, which effectively improved her constipation. Esophagogastroduodenoscopy was performed for progressive reflux symptoms. She was started on a trial of proton pump inhibitor (PPI) therapy with relief of her symptoms. Additionally, infectious disease was consulted for an episode of fever as high as $100.8 \mathrm{~F}$. Due to an absence of infectious etiology, a normal WBC count, negative severe acute respiratory syndrome coronavirus 2 (SARS-CoV-2) testing, and a negative hepatitis panel, the fever was concluded to be secondary to inflammatory changes; as such, no antimicrobial therapy was initiated. Her fever subsequently resolved in 24 hours without intervention.

Throughout her admission, multiple tests were conducted to determine the etiology of her acute liver injury. Testing for hemochromatosis gene variants, ceruloplasmin, alpha-1 anti-trypsin, anti-smooth muscle antibody, mitochondrial antibody, anti-nuclear antibodies, and viral hepatitis were all negative or within the normal range as displayed in (Table 1). Ultimately, a liver biopsy was performed and was significant for inflammatory changes with areas of the portal, periportal, and lobular inflammation. There were focal increases of eosinophils within the inflammatory components, further supporting a diagnosis of DILI (Figures 1-2). Additionally, there were areas of cholestasis accentuated in the perivenular regions. The patient's duloxetine was discontinued with a resulting persistent decline and return of her hepatic enzymes toward baseline, as demonstrated in Table 1 above.

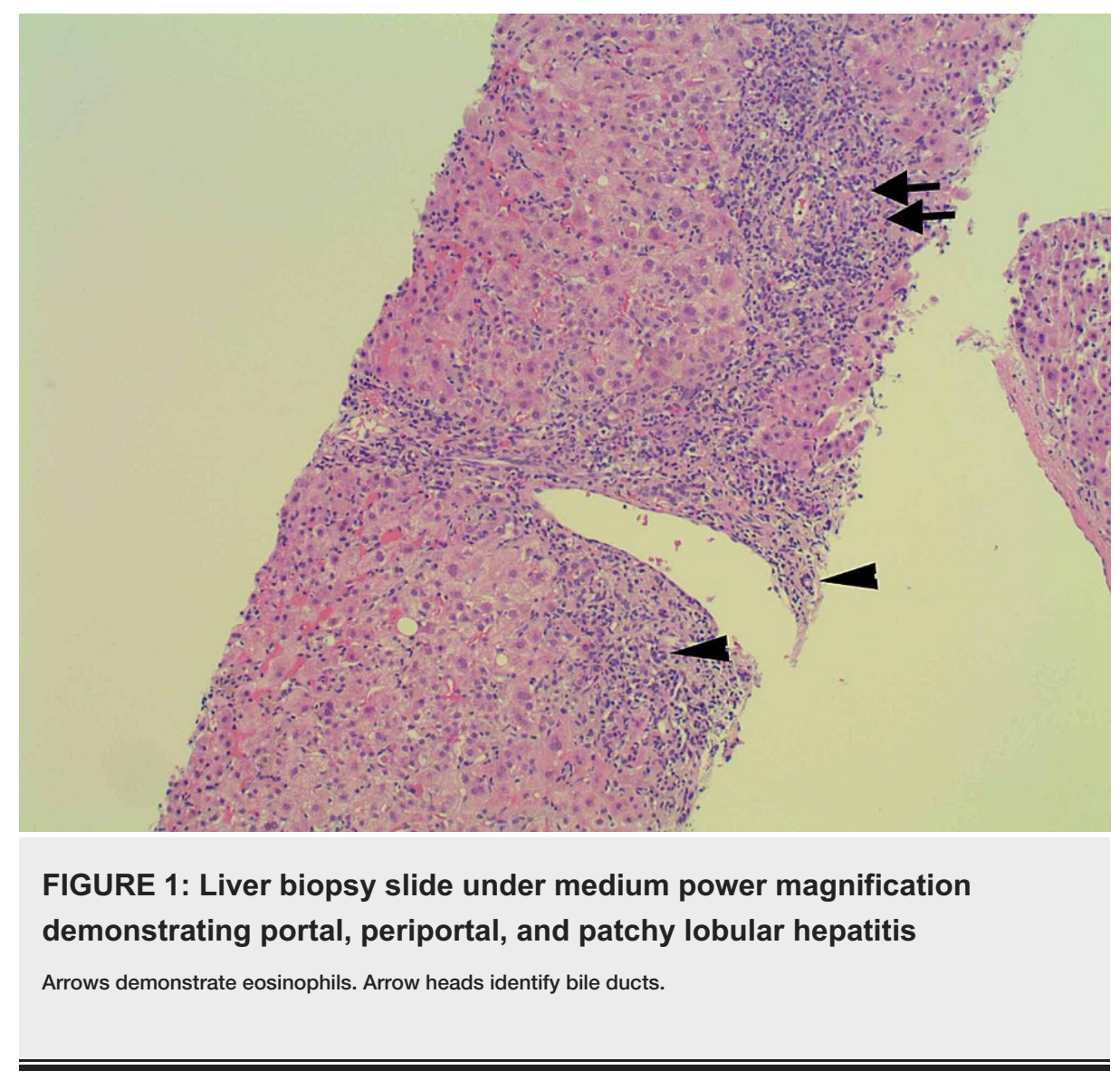




\section{Cureus}

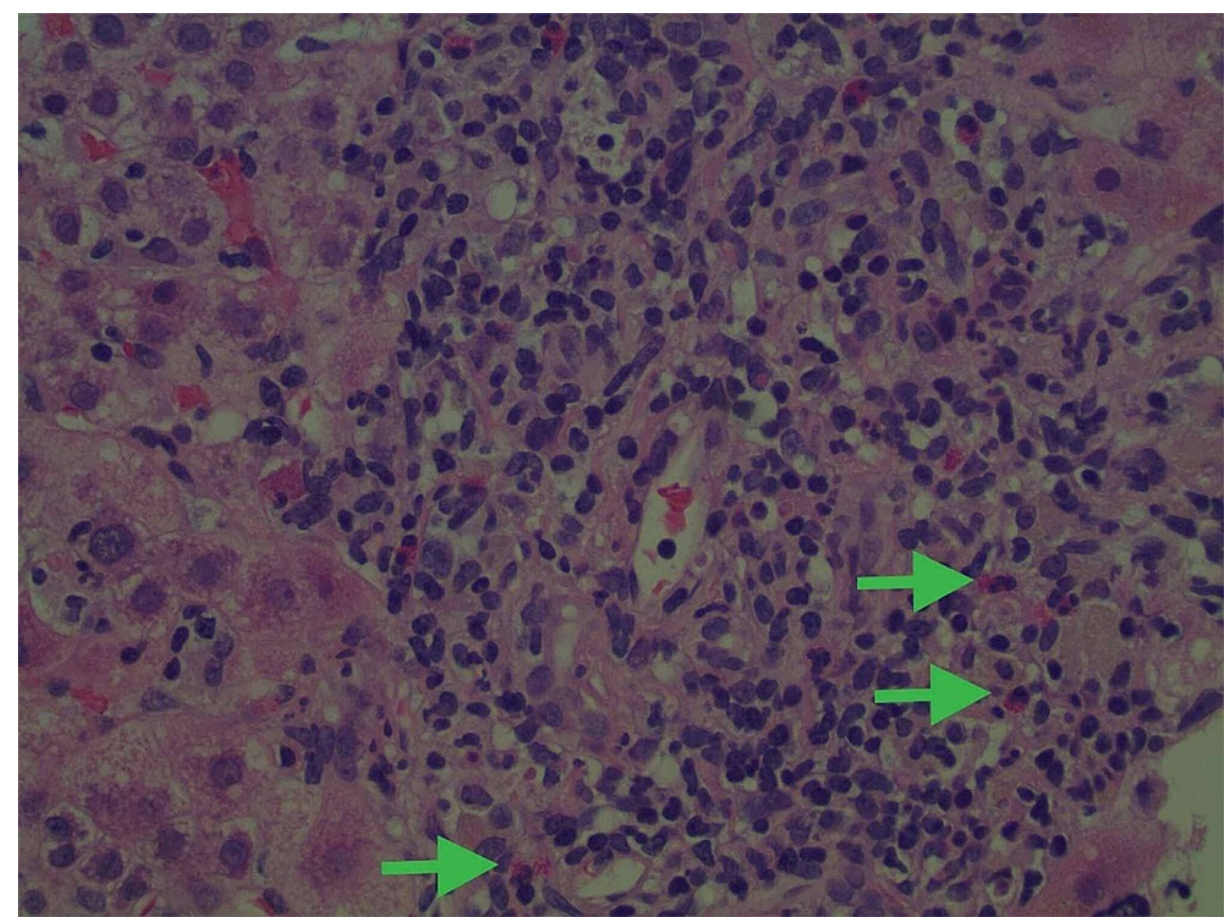

FIGURE 2: Liver biopsy slide under high power magnification showing chronic portal inflammation

Arrows demonstrate eosinophils (pink with granular appearance).

\section{Discussion}

There are typically three patterns of hepatic injury that each has a unique clinical presentation:

hepatocellular (hepatitis), cholestatic (cholestasis), or a mixed picture that includes features of both [5]. Our patient presented with a mixed picture due to the disproportionate elevation in the serum aminotransferase when compared to alkaline phosphatase and increased total bilirubin. However, she still demonstrated a significant elevation in alkaline phosphatase with evidence of cholestasis in the perivenular regions on pathology reports. The additional findings of inflammation with the presence of focal eosinophils in biopsy specimens further support DILI over other mechanisms of hepatotoxicity (Figures 1-2).

Unfortunately, specific serum biomarkers or histologic features that can delineate or identify the exact drug inciting acute liver failure do not exist at this time. Therefore, ascribing DILI to a particular drug requires thorough past medical, familial, social, and medication history gathering, ruling out multiple etiologies of the underlying disease, discontinuation of suspected insulting medication, and monitoring the patient's clinical response-all of which were performed in our patient.

There have been few additional studies published that report a link between the use of duloxetine in patients without liver disease and the development of DILI (Table 2). A review of these cases demonstrates that women are predominantly affected, with a ratio of $8: 2$, and the mean age of insult is 46.5 years old. Our patient falls into these demographics as a female at the age of 43 years old. However, there is currently no established correlation associated with the sex and age of patients as it relates to the risk of hepatic injury. 


\section{Cureus}

\begin{tabular}{|c|c|c|c|c|c|c|c|}
\hline Study & Age/Sex & Type of Injury & $\begin{array}{l}\text { Onset of } \\
\text { Symptoms }\end{array}$ & Risk Factors & Dosage & $\begin{array}{l}\text { Intensive } \\
\text { care unit } \\
\text { (ICU)/Floor }\end{array}$ & Treatment \\
\hline $\begin{array}{l}\text { Yuan W et } \\
\text { al. [6]. }\end{array}$ & 58/Female & Acute Hepatic Failure & Two days & - & $\begin{array}{l}90 \mathrm{mg} / \text { day }(7 \\
\text { weeks) }\end{array}$ & ICU & Protonix, lactulose, IV fluids \\
\hline $\begin{array}{l}\text { Hanje A et } \\
\text { al. [7]. }\end{array}$ & 56/Female & $\begin{array}{l}\text { Fulminant Hepatıc } \\
\text { Failure }\end{array}$ & $\begin{array}{l}\text { Two } \\
\text { weeks }\end{array}$ & - & $\begin{array}{l}60 \mathrm{mg} / \text { day }(6 \\
\text { weeks) }\end{array}$ & Floor & $\begin{array}{l}\text { Lactulose, Fresh frozen plasma, } \\
\text { Recombinant Factor Vlla with } \\
\text { incracranial pressure monitor with } \\
\text { persistent deterioration }\end{array}$ \\
\hline \multirow[t]{7}{*}{$\begin{array}{l}\text { Vuppalanchi } \\
\text { et al. [8]. }\end{array}$} & 37/Male & $\begin{array}{l}\text { Hepatocellular and } \\
\text { cholestatic hepatic } \\
\text { injury }\end{array}$ & Two days & $\begin{array}{l}\text { Chronic } \\
\text { alcoholism }\end{array}$ & $\begin{array}{l}60 \mathrm{mg} / \mathrm{day} \text { (6 } \\
\text { weeks) }\end{array}$ & - & - \\
\hline & 28/Female & Acute Hepatic Necrosis & - & - & $\begin{array}{l}60 \mathrm{mg} / \text { day }(1 \\
\text { month) }\end{array}$ & - & Supportive \\
\hline & 49/Female & $\begin{array}{l}\text { Acute Hepatic Necrosis } \\
\text { superimposed on non- } \\
\text { alcoholic } \\
\text { steatohepatitis }\end{array}$ & - & $\begin{array}{l}\text { Non-alcoholic } \\
\text { fatty liver } \\
\text { disease, } \\
\text { Clonazepam }\end{array}$ & $\begin{array}{l}30 \mathrm{mg} / \text { day ( } 4 \\
\text { weeks) }\end{array}$ & - & - \\
\hline & 56/Female & Cholestatic Hepatitis & - & - & $\begin{array}{l}\text { then dose } \\
\text { increased to } 60 \\
\mathrm{mg} / \text { day ( } 9 \text { weeks) }\end{array}$ & - & - \\
\hline & 49/Female & Cholestatic hepatitis & - & - & $\begin{array}{l}60 \mathrm{mg} / \mathrm{day}(5 \\
\text { weeks) }\end{array}$ & & - \\
\hline & 58/Female & & & $\begin{array}{l}\text { Chronic } \\
\text { hepatitis C, } \\
\text { Acetaminophen } \\
\text { \& Clonazepam }\end{array}$ & $\begin{array}{l}30 \mathrm{mg} / \mathrm{day}(2 \\
\text { weeks) }\end{array}$ & ICU & \\
\hline & 52/Female & Acute Hepatitis & - & $\begin{array}{l}\text { Methotrexate } \\
\text { (3yrs) }\end{array}$ & 60 mg/daily & - & - \\
\hline $\begin{array}{l}\text { Park et al. } \\
\text { [9]. }\end{array}$ & 22 & nolestatic Jaundice & & - & $\begin{array}{l}30 \text { mg/daily, } 60 \\
\text { mg/daily (3 month) }\end{array}$ & - & - \\
\hline
\end{tabular}

TABLE 2: Summary of case studies reporting drug-induced liver injury (DILI)

Additionally, further review of the data suggests that DILI in duloxetine users occurs in an idiosyncratic manner. Thus, the predictability of potential injury is challenging to assess and concrete recommendations for dose management are challenging to make. The average amount of time before patients reported to a physician with clinical symptoms in DILI cases was approximately six weeks (based on review of prior case studies referenced in Table 2). It may be advisable for physicians interested in starting their patients on this medication or making dose adjustments to perform baseline LFTs at initiation and repeat labs at the four-tosix-week point to monitor medication tolerance. Intermittent monitoring alongside routine labs may also be advisable thereafter, as our patient had been on a long term (five year) course of duloxetine prior to the development of DILI.

\section{Conclusions}

DILI in patients that take duloxetine without a history of hepatic disease is a rare entity. We report a case of a 43-year-old, otherwise healthy, female with duloxetine-induced liver injury. She presented with an acute liver injury that improved after the discontinuation of duloxetine. Physicians prescribing this medication should be aware of the potential for liver injury, and may consider monitoring LFTs at baseline, at the fourto-six-week period after initiation or adjustment of duloxetine dosage, and intermittently on routine labs thereafter.

\section{Additional Information}

Disclosures 
Human subjects: Consent was obtained or waived by all participants in this study. Nancy Smith issued approval n/a. Informed consent was obtained from the patient and McLaren Health Care Privacy officer Nancy Smith approved the manuscript for submission. Conflicts of interest: In compliance with the ICMJE uniform disclosure form, all authors declare the following: Payment/services info: All authors have declared that no financial support was received from any organization for the submitted work. Financial relationships: All authors have declared that they have no financial relationships at present or within the previous three years with any organizations that might have an interest in the submitted work. Other relationships: All authors have declared that there are no other relationships or activities that could appear to have influenced the submitted work.

\section{References}

1. Hussaini SH, Farrington EA: Idiosyncratic drug-induced liver injury: an update on the 2007 overview . Expert Opin Drug Saf. 2014, 13:67-81. 10.1517/14740338.2013.828032

2. Ostapowicz G, Fontana RJ, Schiodt FV, et al.: Results of a prospective study of acute liver failure at 17 tertiary care centers in the United States. Ann Intern Med. 2002, 137:947-954. 10.7326/0003-4819-137-12200212170-00007

3. Larson AM, Polson J, Fontana RJ, et al.: Acetaminophen-induced acute liver failure: results of a United States multicenter, prospective study. Hepatology. 2005, 42:1364-1372. 10.1002/hep.20948

4. Chalasani N, Fontana RJ, Bonkovsky HL, et al.: Causes, clinical features, and outcomes from a prospective study of drug-induced liver injury in the United States. Gastroenterology. 2008, 135:1924-1934.E4. 10.1053/j.gastro.2008.09.011

5. Batt AM, Ferrari L: Manifestations of chemically induced liver damage . Clin Chem. 1995, 41:1882-1887.

6. Yuan W, Williams B: Acute hepatic failure involving duloxetine hydrochloride. J Neuropsychiatry Clin Neurosci. 2012, 24:E48-49.

7. Hanje AJ, Pell LJ, Votolato NA, Frankel WL, Kirkpatrick RB: Case report: fulminant hepatic failure involving duloxetine hydrochloride. Clin Gastroenterol Hepatol. 2006, 4:912-917. 10.1016/j.cgh.2006.04.018

8. Vuppalanchi R, Hayashi PH, Chalasani N, et al.: Duloxetine hepatotoxicity: a case-series from the druginduced liver injury network. Aliment Pharmacol Ther. 2010, 32:1174-1183. 10.1111/j.13652036.2010.04449.x

9. Park YM, Lee BH, Lee HJ, Kang SG: Cholestatic jaundice induced by duloxetine in a patient with major depressive disorder. Psychiatry Investig. 2010, 7:228-230. 10.4306/pi.2010.7.3.228 